\title{
Commuter Mode Choice and Free Car Parking, Public Transportation Benefits, Showers/Lockers, and Bike Parking at Work: Evidence from the Washington, DC Region
}

\author{
Andrea Hamre and Ralph Buehler \\ Virginia Tech
}

\begin{abstract}
Municipalities and employers in the U.S. attempt to reduce commuting by automobile through commuter benefits for riding public transportation, walking, or cycling. Many employers provide a combination of benefits, often including free car parking alongside benefits for public transportation, walking, and cycling. This study evaluates the relationship between commuter benefits and mode choice for the commute to work using revealed preference data on 4,630 regular commuters, including information about free car parking, public transportation benefits, showers/lockers, and bike parking at work in the Washington, DC region. Multinomial logistic regression results show that free car parking at work is related to more driving. Commuters offered either public transportation benefits, showers/lockers, or bike parking, but no free car parking, are more likely to either ride public transportation, walk, or cycle to work. The joint provision of benefits for public transportation, walking, and cycling is related to an increased likelihood to commute by all three of these modes and a decreased likelihood of driving. However, the inclusion of free car parking in benefit packages alongside benefits for public transportation, walking, and cycling, seems to
\end{abstract}


offset the effect of these incentives. Benefits for public transportation, walking, and cycling, seem to work best when car parking is not free.

\section{Introduction}

Travel demand management (TDM) objectives include congestion mitigation, conservation of financial and energy resources, pollution reduction, and improvement in health outcomes and quality of life measures (Cervero 1991; Giuliano 1992; TCRP 2002, 2010; FHWA 2012b). At the local and regional levels, planning authorities have begun to implement policies to achieve TDM objectives and increase travel by public transportation, cycling, and walking, including changes to parking fee structures and requirements, zoning ordinances, building codes, and roadway regulations (TCRP 2010).

Another important policy tool to achieve TDM objectives has been the creation and expansion of commuter benefits-although the types and levels of these benefits has varied across both modes and time (Potter et al. 2006; TCRP 2003; EPA 2007; IRS 2013). Free car parking, however, generally continues to be the most prevalent type of benefit offered to commuters; only about 5 percent of auto commuters pay for parking in the U.S., and commuters, on average, avoid direct payment of the majority of actual parking costs (Wachs 1990; Shoup 2005; TCRP 2005; FHWA 2012a).

The interaction effects among commuter benefits have received relatively little attention in the literature, and few commuter mode choice studies jointly include benefits for driving, public transportation, and walking or cycling. However, the importance of policy interactions relating to travel behavior has long been recognized. For example, Pucher (1988) conducted an international comparison of transportation policies, and argued that public transportation benefits in the U.S. are largely rendered ineffective in the absence of complementary automobile taxation policies.

More recently, Washbrook et al. (2006) conducted a study of the effect of road pricing and parking charges on commuter mode choice in Vancouver, Canada, and concluded that effective TDM requires a combination of disincentives for driving and incentives for walking, cycling, and public transportation. Similarly, Habibian and Kermanshah (2011) highlight the push and pull factors for the decision to drive. Also, Marsden (2006) reviewed the literature on behavioral responses to various parking policies and suggested that substantial mode shifts among commuters 
may be achieved when a package of alternatives is introduced along with changes to car parking pricing or supplies.

It remains a question whether, at the level of the individual commuter, packages that offer benefits for driving as well as walking, cycling, and public transportation may effectively promote TDM objectives. This study attempts to address that question and the growing need for understanding the cumulative effects of commuter benefits on travel behavior.

Until recently, commuter benefits for cycling and walking were often omitted from studies regarding transportation mode choice-typically due to their omission from data collection efforts as well as their relatively low level of provision. This study contributes to the literature through the inclusion of commuter benefits for driving, riding public transportation, and walking or cycling to work. In addition, this paper also supplements the existing literature on commuter benefits and mode choice by utilizing revealed preference data on how commuters traveled to work, rather than stated preference data regarding prospective or anticipated behavior.

The data for this analysis originate from the 2007/2008 Washington DC Household Travel Survey. The survey comprises information about free car parking, public transportation benefits, facilities/services for cyclists and pedestrians (such as showers and lockers), and secure bicycle facilities (such as bike parking) at work. A multinomial logistic regression analysis is used to examine the impact of these different types of commuter benefits on mode choice by comparing public transportation users, pedestrians, and cyclists to motorists.

The following section provides a brief overview of the literature on commuter benefits. Then, an empirical analysis investigates the relationship between transportation mode choice for travel to work and commuter benefits for motorists, public transportation users, pedestrians, and cyclists in the Washington, DC region.

\section{Estimating the Impact of Commuter Benefits on Mode Choice}

In recent decades, a substantial body of literature has focused on the effect of car parking pricing on commuter mode choice (FHWA 2012a). For example, Willson and Shoup (1990) conducted a review of empirical studies of car parking subsidies, and found that eliminating free car parking at work reduces single-occupancy vehicle commuting between 19 percent and 81 percent. Another study examined parking subsidies in Los Angeles and found that between 25 and 34 percent fewer 
automobiles were driven to workplaces where workers had to pay to park their cars (Willson 1992). Shoup (1997) reviewed the effects of car parking "cash out" programs and found that single-occupancy vehicle commuting fell by 17 percent among 8 case study firms after they complied with California's cash-out requirement. More recently, an analysis of parking subsidies in Portland, Oregon, found that a daily car parking charge of $\$ 6$ reduced single-occupancy vehicle commuting by an estimated 16 percent (Hess 2001).

Another important area of inquiry has been the effect of public transportation pricing on commuter mode choice. For example, two studies of the UCLA BruinGo fare-free program found increases in bus ridership and declines in driving corresponding to the launch of the program (Brown, Hess, and Shoup 2003; Boyd et al. 2003). Another study examined the efficacy of a proposed "mobility pass" at the Massachusetts Institute of Technology (MIT) that would combine parking and public transportation benefit programs, and predicted that both single-occupancy vehicle commuting and overall commuter costs would decrease (Block-Schachter 2009).

Increasing attention is being devoted to the effect of benefits for walking and cycling on commuter mode choice. Studies measuring the effect of direct subsidies for walking and cycling are still rare, likely due to the relatively scarce provision of these types of benefits and a related lack of available data. One study from the U.K. supplemented stated- and revealed-preference primary data with the National Travel Survey to forecast that direct payments could significantly increase cycling commuting rates (Wardman, Tight, and Page 2007). More commonly, studies focusing on cycling and walking assess the effect of facilities and services such as bicycle parking, workplace showers, and shared-use paths (Dill and Wardell 2007; Buehler 2012). In many studies, public transportation, walking, and cycling are considered complementary (Bachand-Marleau, Larsen, and El-Geneidy 2011; Pucher 2004). However, Boyd et al. (2003) found a decrease in walking and cycling to campus after the fare-free public transportation program's introduction. Dill and Wardell (2007) also found bike amenities to be negatively correlated with public transportation use in their study of factors affecting mode choice in Portland, Oregon. In addition, low-cost public transportation passes for students have corresponded with decreased cycling in some Dutch and German cities (Pucher and Buehler 2012). 
Few studies on commuter mode choice concurrently include variables measuring benefits for driving, public transportation, walking, and cycling. One study randomly sampled firms identified as "best workplaces for commuters" in several metropolitan areas in the U.S. and found that comprehensive benefit packages could reduce vehicle miles traveled and pollutants by about 15 percent (Herzog et al. 2006). Another study modeled public transportation commuter mode share using worksite-level data from Portland, Oregon, and found public transportation benefits and bike amenities to be significant predictors for commuting by public transportation, walking, and cycling. The study did not assess the provision of worksite-specific free car parking; rather, it attempted to control for free car parking via a dummy variable for the downtown "Fareless Square" area, where free car parking was much less likely (Dill and Wardell 2007).

Overall, the relationship between commuter benefits and mode choice has been examined using a variety of methodologies and in a variety of settings. Some studies have surveyed employers, while others have surveyed commuters. The literature to date suggests a correlation between the provision of commuter benefits and a commuter's transportation mode choice, with free car parking associated with higher rates of single-occupancy vehicle commuting, public transportation benefits associated with higher rates of public transportation use, and walking and cycling benefits associated with higher rates of walking and cycling to work.

Selection bias continues to be a concern in interpreting these findings, as selfselection into residential and workplace settings may influence the perceived relationship between commuter benefits and transportation mode choice. Further, studies of this subject have typically relied on cross-sectional and observational data and that is also the case in our study. These types of studies suffer from the potential for endogeneity and selection bias, so findings suggest correlations, but cannot assess causality regarding the relationship between transportation mode choice and commuter benefits.

The present study contributes to this literature by using revealed preference data via a household travel survey and incorporates commuter benefits for driving, public transportation, and walking or cycling. The literature review guided the selection of explanatory variables included in the analysis. Most studies of transportation mode choice for the commute include demographic, socioeconomic, and geographic measures as explanatory variables. Variations across studies are often due, in part, to differences in data availability and travel survey design. 


\section{Study Area: The Washington, DC Region}

This study focuses on commutes in the urban core and inner suburbs of the Washington, DC region. The urban core of the Washington, DC metropolitan area comprises Washington, DC, along with Arlington County and the city of Alexandria in Virginia. In addition, Fairfax County in Virginia and Montgomery and Prince George's counties in Maryland are lower-density, inner-suburban jurisdictions bordering the urban core of the region. Together, these five jurisdictions have a population of approximately 3.8 million inhabitants (USCB 2010). Median household income is higher in the region than the national average, and except for Arlington County, area jurisdictions have higher shares of nonwhite populations than the national average. The share of households who do not own a vehicle varies significantly between the urban core and inner suburbs. For example, about 35 percent of households in Washington, DC do not own an automobile compared to only about 4 percent of households in Fairfax County (USCB 2010).

The Washington Metropolitan Area Transit Authority (WMATA) operates one of the most extensive public transportation systems in the U.S., including the second largest metro rail system and sixth largest bus system (WMATA 2011). According to the Metropolitan Washington Council of Governments (MWCOG) 2007 State of the Commute Survey Report, 83 percent of commuters in the region had bus or train service near their home at that time and 79 percent had some form of public transportation near their workplace (MWCOG 2007). The region has been recognized as an example of successful transit coordination, where transit agencies and the MWCOG metropolitan planning organization meet regularly (Rivasplata, Smith, and Iseki 2012). In addition, the region also has notorious automobile traffic congestion, ranking first in 2011 among the 15 largest areas in the country in yearly delay per auto commuter (TTI 2011) and has significantly increased levels of cycling and accompanying infrastructure and programming for active travel in recent decades (Buehler 2011).

\section{Data Sources, Variables, and Model Development}

Data for this analysis originate primarily from the 2007/2008 DC Household Travel Survey conducted by the Metropolitan Washington Council of Governments' (MWCOG) Transportation Planning Board. The survey is representative of the region and consisted of an introductory household questionnaire-which collected demographics and socioeconomics-as well as a travel diary to gather in-depth information on daily travel on a specifically assigned travel day for each household member (MWCOG 2010). The survey collected information on the 
provision of free car parking, public transportation benefits, facilities/services for cyclists and pedestrians (such as showers and lockers), and secure bicycle facilities (such as bike parking) at work. The survey is particularly useful for assessing the relationship between commuter benefits and an individual's commute mode choice. The final sample includes 4,630 adult full-time workers living in the urban core or inner suburbs and commuting to regular workplaces using a reported usual mode to work. For this analysis, data on transit access, bikeway supply, population, and land area were merged with the travel survey dataset using 2,155 traffic analysis zone (TAZ) identifiers.

The analysis is comprised of a reduced multinomial logistic regression, which models the effect of commuter benefits on mode choice, and a full multinomial logistic regression, which models the effect of commuter benefits on mode choice while controlling for other relevant neighborhood-, household-, and person-level characteristics. The full model is the preferred specification, because it incorporates additional theoretically relevant variables beyond the commuter benefit measures. The dependent variable in both the reduced and full models is the commuter's transportation mode choice among driving, public transportation, walking, and cycling, based on the survey question, "How did you usually get to work last week?" Survey respondents who used more than one mode were directed to provide the mode used for the most distance or the mode that took the most time (MWCOG 2010). We used Hausman and Small-Hsiao tests to evaluate the Independence of Irrelevant Alternatives assumption for the multinomial logit models, and both produced mixed results. However, these tests are sensitive to model parameterization. Theory and judgment led us to determine that the four mode choices used in the multinomial logit could be treated as distinct choice sets for commuters. As a result, we chose to use the multinomial logit, although separately run binomial logit models produced similar results overall.

The key explanatory variables are commuter benefit measures of free car parking, public transportation benefits, bike/walk benefits (showers/lockers and/or bike parking), and combinations of these benefit types, as summarized in Table 1. Table 2 summarizes the variable names, definitions, and descriptive statistics for the model. The reduced model contains only the commuter benefit measures as explanatory variables. 


\section{Table 1. Commuter Benefit Combinations Used as Explanatory Variables}

\begin{tabular}{|c|c|c|c|c|}
\hline Variable Name & Description & $\begin{array}{c}\text { Free } \\
\text { Car } \\
\text { Parking }\end{array}$ & $\begin{array}{c}\text { Public } \\
\text { Transportation } \\
\text { Benefits }\end{array}$ & $\begin{array}{l}\text { Showers/ } \\
\text { Lockers } \\
\text { and/or Bike } \\
\text { Parking } \\
\end{array}$ \\
\hline Free Car Parking & $\begin{array}{l}\text { Free car parking, no public } \\
\text { transportation benefits, } \\
\text { no showers/lockers or bike } \\
\text { parking }\end{array}$ & $x$ & & \\
\hline $\begin{array}{l}\text { Public } \\
\text { Transportation } \\
\text { Benefits }\end{array}$ & $\begin{array}{l}\text { No free car parking, public } \\
\text { transportation benefits, } \\
\text { no showers/lockers or bike } \\
\text { parking }\end{array}$ & & $\mathrm{X}$ & \\
\hline $\begin{array}{l}\text { Bike/Walk } \\
\text { Benefits }\end{array}$ & $\begin{array}{l}\text { No free car parking, no public } \\
\text { transportation benefits, } \\
\text { showers/lockers and/or bike } \\
\text { parking }\end{array}$ & & & $\mathrm{X}$ \\
\hline $\begin{array}{l}\text { Public } \\
\text { Transportation } \\
\text { Benefits \& Bike/ } \\
\text { Walk Benefits }\end{array}$ & $\begin{array}{l}\text { No free car parking, public } \\
\text { transportation benefits, } \\
\text { showers/lockers and/or bike } \\
\text { parking }\end{array}$ & & $x$ & $x$ \\
\hline $\begin{array}{l}\text { Free Car } \\
\text { Parking } \\
\text { \& Public } \\
\text { Transportation } \\
\text { Benefits }\end{array}$ & $\begin{array}{l}\text { Free car parking, public } \\
\text { transportation benefits, } \\
\text { no showers/lockers or bike } \\
\text { parking }\end{array}$ & $x$ & $x$ & \\
\hline $\begin{array}{l}\text { Free Car Parking } \\
\text { \& Bike/Walk } \\
\text { Benefits }\end{array}$ & $\begin{array}{l}\text { Free car parking, no public } \\
\text { transportation benefits, } \\
\text { showers/lockers and/or bike } \\
\text { parking }\end{array}$ & $\mathrm{X}$ & & $x$ \\
\hline All Benefits & $\begin{array}{l}\text { Free car parking, public } \\
\text { transportation benefits, } \\
\text { showers/lockers and/or bike } \\
\text { parking }\end{array}$ & $x$ & $x$ & $x$ \\
\hline
\end{tabular}


Table 2. Variable Names, Measurement/Description, and Descriptive Statistics

\begin{tabular}{|c|c|c|}
\hline Variable Name & Measurement/Description & Descriptive Statistics \\
\hline Mode Choice & $\begin{array}{l}\text { Nominal variable. Value of } 0 \text { if respondent } \\
\text { drove alone to work, } 1 \text { if rode public } \\
\text { transportation, } 2 \text { if walked, } 3 \text { if cycled. }\end{array}$ & $\begin{array}{l}70.1 \% \text { drove alone, } 24.1 \% \\
\text { rode public transportation, } \\
4.1 \% \text { walked, } 1.6 \% \text { cycled }\end{array}$ \\
\hline $\begin{array}{l}\text { Free Car } \\
\text { Parking }\end{array}$ & $\begin{array}{l}\text { Nominal variable. Value of } 1 \text { if workplace } \\
\text { provides free car parking and no other } \\
\text { benefit, } 0 \text { otherwise. }\end{array}$ & $\begin{array}{l}20.7 \% \text { have free car parking } \\
\text { at work and no other benefit }\end{array}$ \\
\hline $\begin{array}{l}\text { Public } \\
\text { Transportation } \\
\text { Benefits }\end{array}$ & $\begin{array}{l}\text { Nominal variable. Value of } 1 \text { if workplace } \\
\text { provides transit or vanpooling benefits and } \\
\text { no other benefit, } 0 \text { if otherwise }\end{array}$ & $\begin{array}{l}6.9 \% \text { have transit or } \\
\text { vanpooling benefits at work } \\
\text { and no other benefit }\end{array}$ \\
\hline $\begin{array}{l}\text { Bike/Walk } \\
\text { Benefits }\end{array}$ & $\begin{array}{l}\text { Nominal variable. Value of } 1 \text { if workplace } \\
\text { provides showers/lockers and/or bike parking, } \\
\text { and no other benefit, } 0 \text { if otherwise }\end{array}$ & $\begin{array}{l}15.5 \% \text { have showers/lockers } \\
\text { and/or bike parking and no } \\
\text { other benefit }\end{array}$ \\
\hline $\begin{array}{l}\text { Public Trans- } \\
\text { portation } \\
\text { Benefits \& Bike/ } \\
\text { Walk Benefits }\end{array}$ & $\begin{array}{l}\text { Nominal variable. Value of } 1 \text { if workplace } \\
\text { provides transit or vanpooling benefits and } \\
\text { showers/lockers and/or bike parking and no } \\
\text { other benefit, } 0 \text { if otherwise. }\end{array}$ & $\begin{array}{l}12.2 \% \text { have transit or } \\
\text { vanpooling benefits and } \\
\text { showers/lockers and/or bike } \\
\text { parking and no other benefit }\end{array}$ \\
\hline $\begin{array}{l}\text { Free Car } \\
\text { Parking \& } \\
\text { Public } \\
\text { Transportation } \\
\text { Benefits }\end{array}$ & $\begin{array}{l}\text { Nominal variable. Value of } 1 \text { if workplace } \\
\text { provides free car parking and transit or } \\
\text { vanpooling benefits and no other benefit, } 0 \text { if } \\
\text { otherwise. }\end{array}$ & $\begin{array}{l}2.4 \% \text { have free car parking } \\
\text { and transit or vanpooling } \\
\text { benefits, but no other } \\
\text { benefit }\end{array}$ \\
\hline $\begin{array}{l}\text { Free Car } \\
\text { Parking \& Bike/ } \\
\text { Walk Benefits }\end{array}$ & $\begin{array}{l}\text { Nominal variable. Value of } 1 \text { if workplace } \\
\text { provides free car parking and showers/lockers } \\
\text { and/or bike parking and no other benefit, } 0 \text { if } \\
\text { otherwise. }\end{array}$ & $\begin{array}{l}\text { 19.4\% have free car parking } \\
\text { and showers/lockers and/or } \\
\text { bike parking and no other } \\
\text { benefit }\end{array}$ \\
\hline All Benefits & $\begin{array}{l}\text { Nominal variable. Value of } 1 \text { if workplace } \\
\text { provides free car parking, transit or } \\
\text { vanpooling benefits, and showers/lockers } \\
\text { and/or bike parking, } 0 \text { if otherwise. }\end{array}$ & $\begin{array}{l}2.3 \% \text { have free car parking, } \\
\text { transit or vanpooling } \\
\text { benefits, and showers/ } \\
\text { lockers and/or bike parking }\end{array}$ \\
\hline Race/Ethnicity & $\begin{array}{l}\text { Nominal variable. Value of } 1 \text { if respondent is } \\
\text { white, } 0 \text { if otherwise. }\end{array}$ & $69.2 \%$ white \\
\hline Gender & $\begin{array}{l}\text { Nominal variable. Value of } 1 \text { if respondent is } \\
\text { male, } 0 \text { if respondent is female. }\end{array}$ & $49.5 \%$ male \\
\hline Age & Integer variable. & Mean: 44 (Std. Dev.: 13) \\
\hline Income & $\begin{array}{l}\text { Nominal variable. Value of } 1 \text { if respondent } \\
\text { lives in approximately wealthiest } 25 \% \\
\text { (quartile) of households, } 0 \text { if otherwise. }\end{array}$ & $\begin{array}{l}35.4 \% \text { in highest income } \\
\text { quartile }\end{array}$ \\
\hline
\end{tabular}




\begin{tabular}{|c|c|c|}
\hline Variable Name & Measurement/Description & Descriptive Statistics \\
\hline $\begin{array}{l}\text { Any Children in } \\
\text { Household }\end{array}$ & $\begin{array}{l}\text { Nominal variable. Value of } 1 \text { if respondent } \\
\text { lives in household with one or more minors } \\
\text { (under 18). }\end{array}$ & $\begin{array}{l}30.7 \% \text { live in a household } \\
\text { with at least one minor }\end{array}$ \\
\hline Car Access & Ratio variable. Cars per household member. & Mean: 0.827 (Std. Dev.: 0.451) \\
\hline Bicycle Access & $\begin{array}{l}\text { Ratio variable. Bicycles per household } \\
\text { member. }\end{array}$ & Mean: 0.536 (Std. Dev.: 0.623) \\
\hline $\begin{array}{l}\text { Commute } \\
\text { Distance } \\
\text { (Natural Log) }\end{array}$ & $\begin{array}{l}\text { Continuous variable. Natural log of distance } \\
\text { reported for commute trip. }\end{array}$ & Mean: 1.592 (Std. Dev.: 1.308) \\
\hline $\begin{array}{l}\text { Population } \\
\text { Density }\end{array}$ & $\begin{array}{l}\text { Ratio variable. Persons per acre of land area in } \\
\text { home TAZ. }\end{array}$ & $\begin{array}{l}\text { Mean: } 15.741 \text { (Std. Dev.: } \\
\text { 16.537) }\end{array}$ \\
\hline Urban Core & $\begin{array}{l}\text { Nominal variable. Value of } 1 \text { if respondent } \\
\text { lives in Washington DC, Arlington County, } \\
\text { or Alexandria; } 0 \text { if respondent lives in Fairfax } \\
\text { County; Montgomery County; or Prince } \\
\text { George's County. }\end{array}$ & $36.8 \%$ live in urban core \\
\hline Transit Access & $\begin{array}{l}\text { Count variable. Number of Metro Rail } \\
\text { stations in home TAZ. }\end{array}$ & Mean: 0.051 (Std. Dev.: 0.246) \\
\hline Bikeway Supply & $\begin{array}{l}\text { Ratio variable. Centerline miles of bike lanes } \\
\text { and paths per } 1000 \text { residents in home TAZ. }\end{array}$ & Mean: 0.097 (Std. Dev.: 0.955) \\
\hline Season & $\begin{array}{l}\text { Nominal variable. Value of } 1 \text { if travel day was } \\
\text { between May and October, } 0 \text { if otherwise. }\end{array}$ & $\begin{array}{l}45.2 \% \text { of respondents were } \\
\text { interviewed between May } \\
\text { and October }\end{array}$ \\
\hline
\end{tabular}

Several control variables are included in the full model. Measures of race/ethnicity, gender, and age are included as factors that may influence mode choice. Race/ ethnicity has been examined as a relevant factor in mode choice, especially in the context of residential segregation and the spatial mismatch literature (Taylor and Ong 1995; Stoll 2005). Gender has been examined as an influence on travel behavior in relation to such factors as safety perceptions and child-caring responsibilities (Blumenberg 2002; Goddard et al. 2006). Age has also been examined in other mode choice studies relating to changes such as time availability (Cervero 1990; Hess 2001). Measures of income and car and bicycle access are included as factors related to resource availability that may influence mode choice. Car and bicycle access are not perfect measures, since they do not take into account whether the respondent has a driver's license or is able to drive a car or ride a bicycle. However, they are commonly-used control variables that approximate access to resources that may influence mode choice. A measure of commute distance is included. 
Walking and cycling in particular are expected to be sensitive to distance, and mode choice studies often find it to be a significant factor (Cervero and Duncan 2003; Saelens, Sallis, and Frank 2003; Winters et al. 2010; Buehler 2012; Ewing and Cervero 2010). A logarithmic transformation was performed to improve the normality of the distribution of the distance variable. In addition, whether an individual lives in a household with one or more minors is included, since mode choice has been found to be sensitive to the presence of children, especially for women (Goddard et al. 2006).

Residential population density is included, as this measure has been found to be a significant environmental correlate for travel behavior and could relate to differences in street connectivity and urban design (Saelens, Sallis, and Frank 2003; Ewing and Cervero 2010). A dummy variable is also included to capture if a commuter lives in the urban core (Washington, DC, Arlington County, or Alexandria), as opposed to the inner suburbs (Fairfax County, Montgomery County, or Prince George's County). Residents of the urban core are likely to have access to higher levels of public transportation service and a more integrated and extensive active travel network. In addition, they may also interact with drivers who are more aware of pedestrians and cyclists due to heightened promotional programs for alternatives to driving and the more prevalent "safety in numbers" effect in urban areas (Ewing and Dumbaugh 2009; Pucher, Dill, and Handy 2010; Pucher, Garrard, and Greaves 2011).

In addition, a measure of transit access is included, based on the number of Metro Rail stations located in the residential traffic analysis zone (TAZ). While this is an imperfect measure, since TAZs vary in size, it is a general approximation of transit access and is expected to be positively correlated with public transportation use. Bikeway supply is also included, as measured by the miles of bike lanes and paths per 1,000 residents, and is expected to be positively correlated with cycling. Finally, a binary explanatory measure is included for whether the respondent was interviewed between May and October to control for potential seasonal effects on mode choice.

As presented in Table 2, the majority of commuters in our sample drove alone to work (70.1\%). In addition, 20.7 percent reported the availability of free car parking and no other benefits, while about 6.9 percent reported the availability of public transportation benefits and no other benefits. In addition, roughly 15.5 percent reported being offered bike/walk benefits at work but no free car parking or public transportation benefits. About 36 percent reported receiving some combination 
of benefits, including about 2.3 percent of commuters who reported being offered free car parking, public transportation benefits, and bike/walk benefits. Approximately 21 percent of the sample receives none of the benefits (neither free car parking, public transportation benefits, nor bike/walk benefits).

\section{Results}

Table 3 presents results for the reduced and full multinomial logit regression analyses, which examine the relationships between commuter benefits and mode choice. The reduced model includes only the commuter benefit measures as explanatory variables, while the full model comprises the commuter benefit measures and the additional control variables discussed above. Tests of model fit indicate all variables have joint significance in both models. In addition, both Likelihood-Ratio and Wald tests of the reduced versus the full model indicate that the full model adds significant explanatory power when compared to the reduced model (Likelihood-Ratio test statistic $=1,223.14, p<0.01$; Wald test statistic $=917.9$, $\mathrm{p}<0.01$ ). The pseudo- $\mathrm{R}^{2}$ for the reduced and full models, 0.231 and 0.398 respectively, are comparable to the model fits achieved in other transportation mode choice studies of similar subjects (Dill and Wardell 2007, Buehler 2012). In addition, we performed several multicollinearity tests, and found it is not a significant concern among the explanatory and control variables (Mean VIF $=1.25$, Tolerance > 0.6 , Condition Number $=18.2$ ).

The results for each of the explanatory variables displayed in Table 3 can be interpreted based on sign, magnitude, and statistical significance. Coefficients have been transformed into odds ratios, which give the proportionate change in the relative risk of choosing a given alternative, rather than the reference category (Cameron and Trivedi 2010). In this case, they represent the likelihood of choosing to commute by public transportation, walking, or cycling relative to the base category of driving alone, while controlling for other variables in the analysis. 
Commuter Mode Choice and Free Car Parking, Public Transportation Benefits, Showers/ Lockers, and Bike Parking at Work: Evidence from the Washington, DC Region

\section{Table 3. Results of Multinomial Logit Model of Transportation Mode Choice and Commuter Benefits in the Washington, DC Region}

\begin{tabular}{|c|c|c|c|c|c|c|}
\hline \multirow[b]{2}{*}{ Variable Name } & \multicolumn{2}{|c|}{ Public Transportation } & \multicolumn{2}{|c|}{ Walk } & \multicolumn{2}{|c|}{ Cycle } \\
\hline & $\begin{array}{l}\text { Reduced } \\
\text { Model }\end{array}$ & $\begin{array}{c}\text { Full } \\
\text { Model }\end{array}$ & $\begin{array}{c}\text { Reduced } \\
\text { Model }\end{array}$ & $\begin{array}{c}\text { Full } \\
\text { Model }\end{array}$ & $\begin{array}{c}\text { Reduced } \\
\text { Model }\end{array}$ & $\begin{array}{c}\text { Full } \\
\text { Model }\end{array}$ \\
\hline Free Car Parking & $0.082^{* * *}$ & $0.098^{* * *}$ & $0.213^{* * *}$ & $0.310^{* * *}$ & $0.102^{* * *}$ & $0.144^{* *}$ \\
\hline $\begin{array}{l}\text { Public Transportation } \\
\text { Benefits }\end{array}$ & $8.428^{* * *}$ & $11.337^{* * *}$ & $2.315^{* *}$ & $2.006^{*}$ & 1.908 & 2.024 \\
\hline Bike/Walk Benefits & 0.926 & 0.945 & $1.628^{* *}$ & 1.503 & $2.464^{* *}$ & $2.119^{*}$ \\
\hline $\begin{array}{l}\text { Public Transportation } \\
\text { Benefits and Bike/Walk } \\
\text { Benefits }\end{array}$ & $8.087^{* * *}$ & $9.627^{* * *}$ & $2.844^{* * *}$ & $2.549 * * *$ & $7.617^{* * *}$ & $6.257^{* * *}$ \\
\hline $\begin{array}{l}\text { Free Car Parking and Public } \\
\text { Transportation Benefits }\end{array}$ & $0.622^{*}$ & 0.670 & 0.453 & 0.358 & 0.540 & 0.475 \\
\hline $\begin{array}{l}\text { Free Car Parking and Bike/ } \\
\text { Walk Benefits }\end{array}$ & $0.096^{* * *}$ & $0.117^{* * *}$ & $0.340^{* * *}$ & $0.593^{*}$ & $0.387^{* *}$ & 0.495 \\
\hline All Benefits & $0.472^{* *}$ & $0.479 * *$ & $0.153^{*}$ & 0.267 & 1.639 & 1.171 \\
\hline Race/Ethnicity (white $=1$ ) & & 1.021 & & $2.550^{* * *}$ & & $2.391^{* *}$ \\
\hline Gender $($ male $=1)$ & & 1.163 & & $1.414^{*}$ & & $3.022^{* * *}$ \\
\hline Age & & 0.995 & & 0.999 & & 0.997 \\
\hline Income & & $0.719^{* * *}$ & & 0.881 & & $1.646^{*}$ \\
\hline Any Children in Household & & $0.285^{* * *}$ & & $0.202^{* * *}$ & & 0.658 \\
\hline Car Access & & $0.092^{* * *}$ & & $0.079 * * *$ & & $0.059^{* * *}$ \\
\hline Bicycle Access & & 1.093 & & 1.007 & & $4.191^{* * *}$ \\
\hline $\begin{array}{l}\text { Commute Distance } \\
\text { (Natural Log) }\end{array}$ & & 0.967 & & $0.414^{* * *}$ & & $0.679 * * *$ \\
\hline Population Density & & $1.011^{* * *}$ & & $1.033^{* * *}$ & & $1.019^{* * *}$ \\
\hline Urban Core & & $1.337^{* *}$ & & $1.493^{*}$ & & $2.448^{* * *}$ \\
\hline Transit Access & & $1.475^{* *}$ & & 1.336 & & 0.825 \\
\hline Bikeway Supply & & 0.983 & & $1.065^{*}$ & & $1.080^{* * *}$ \\
\hline Season & & 1.053 & & 1.063 & & $1.878^{* *}$ \\
\hline
\end{tabular}

*Significant at $10 \%$; ${ }^{* *}$ Significant at $5 \%$; ${ }^{* * *}$ Significant at $1 \%$

Odds ratios after multinomial logit for decision to commute.

Dependent Variable $=$ Mode Choice

Base Outcome $=$ Driving

Reduced Model Fit: Wald Chi^2 = $1056.4(p<0.01) ; L R$ Chi^2 = 1,693.2 $(p<0.01)$; pseudo- $R^{\wedge} 2=0.231$

Full Model Fit: Wald Chi^2 = $1721.5(p<0.01) ; L R$ Chi^2 = 2,916.3 $(p<0.01) ;$ pseudo- $R^{\wedge} 2=0.398$

$N: 4,630$ 
As described above, the full model is the preferred specification, since it incorporates control variables that are theoretically expected to be relevant for the commute mode choice. The signs and magnitudes of the commuter benefit variables are stable between the reduced and full models, but some shifts in significance occur. We emphasize the full model results in the presentation and discussion below.

Controlling for other variables and benefit combinations, commuters with free parking at work (but no public transportation benefits, or bike/walk benefits), were less likely to choose to commute by public transportation (odds ratio of 0.098), walking (odds ratio of 0.310 ), or cycling (odds ratio of 0.144 ) over driving.

Likewise, commuters with employers who only offer public transportation benefits are about 11 times more likely to take public transportation than to drive. Commuters with only public transportation benefits are also more likely to choose walking over driving. Bike/walk benefits were significantly correlated with choosing to cycle to work over driving (odds ratio of 2.119).

The combination of public transportation benefits and bike/walk benefits is strongly correlated with choosing public transportation (odds ratio of 9.627), walking (odds ratio of 2.549), or cycling (odds ratio of 6.257) over driving to work. The combination of free car parking and benefits for public transportation (but no bike/walk benefits) is not significantly correlated with transportation mode choice for the commute, while the combination of free car parking and bike/walk benefits is negatively correlated with choosing public transportation and walking. Simultaneous provision of all benefit types at work (free car parking, public transportation benefits, and bike/walk benefits) corresponds to lower odds for choosing public transportation and is not correlated with walking and cycling.

Summarizing key results regarding the additional control variables, the full model suggests that car access is associated with a strongly reduced likelihood of riding public transportation (odds ratio of 0.092), walking (odds ratio of 0.079), or cycling to work (odds ratio of 0.059 ), while population density and residence in the urban core are both associated with an increased likelihood of riding public transportation (odds ratios of 1.011 and 1.337, respectively), walking (odds ratios of 1.022 and 1.493, respectively), and cycling to work (odds ratios of 1.019 and 2.448, respectively). Race/ethnicity, gender, commute distance, and bikeway supply are associated with differing odds for walking and cycling to work, but not for riding public transportation, while the presence of children is associated with differing odds for riding public transportation and walking to work but not for cycling. Bicycle access 
is associated with increased odds of cycling to work (odds ratio of 4.191) while transit access is associated with a greater likelihood of riding public transportation to work (odds ratio of 1.475).

In addition to odds ratios, the results may also be presented as predicted probabilities based on specific values assigned to the explanatory and control variables (Small and Verhoef 2007). Table 4 presents the predicted probabilities for mode choice outcomes based on the premise of a single commuter benefit package. For each row, the indicated benefit package is held at a value of one while the rest of the benefit categories are held at a value of zero and the control variables are held at their mean sample values.

Table 4. Predicted Probabilities for Mode Choice Outcomes Based upon Different Commuter Benefit Packages (Holding Other Commuter Benefit Packages at Zero and Control Variables at Mean Values)

\begin{tabular}{|l|c|c|c|c|}
\hline \multicolumn{1}{|c|}{ Variable } & $\begin{array}{c}\text { Drive } \\
\text { Alone }\end{array}$ & $\begin{array}{c}\text { Public } \\
\text { Transportation }\end{array}$ & Walk & Cycle \\
\hline No Benefits & $75.9 \%$ & $22.3 \%$ & $1.4 \%$ & $0.5 \%$ \\
\hline Free Car Parking & $96.6 \%$ & $2.8 \%$ & $0.6 \%$ & $0.1 \%$ \\
\hline Public Transportation Benefits & $22.8 \%$ & $76.1 \%$ & $0.8 \%$ & $0.3 \%$ \\
\hline Bike/Walk Benefits & $75.9 \%$ & $21.1 \%$ & $2.1 \%$ & $1.0 \%$ \\
\hline Public Transportation Benefits \& Bike/Walk Benefits & $25.6 \%$ & $72.3 \%$ & $1.2 \%$ & $1.0 \%$ \\
\hline Free Car Parking \& Public Transportation Benefits & $82.9 \%$ & $16.3 \%$ & $0.5 \%$ & $0.2 \%$ \\
\hline Free Car Parking \& Bike/Walk Benefits & $95.4 \%$ & $3.3 \%$ & $1.0 \%$ & $0.3 \%$ \\
\hline All Benefits & $86.8 \%$ & $12.2 \%$ & $0.4 \%$ & $0.6 \%$ \\
\hline
\end{tabular}

Free car parking alone is associated with a 96.6 percent probability to drive alone to work-an increase of about 20 percentage points compared to when no benefits are provided. The simultaneous provision of free car parking, public transportation benefits, and bike/walk benefits is associated with an 86.8 percent probability of driving, an increase of about 10 percentages points compared to the probability when no benefits are provided. In general, the combination of free car parking with the other benefit categories is associated with an increased probability of driving alone to work. In contrast, benefits for choosing public transportation, walking, and cycling, when not combined with free car parking, are associated with either the same or reduced probabilities of driving alone. 
To compare the model's overall predictive capacity relative to the mode choice sample summary statistics presented in Table 2, we account for the proportional presence in the sample of each benefit package presented in Table 4 and arrive at predicted mode shares of 74.6 percent for the drive alone outcome, 26.2 percent for public transportation, 1.2 percent for walking, and 0.5 percent for cycling. As a result, our model over-predicts the drive alone ( 4.5 percentage points) and public transportation (2.1 percentage points) outcomes, and under-predicts the walking (2.9 percentage points) and cycling (1.1 percentage points) outcomes. Since the walking and cycling mode choice outcomes are relatively rare events in our data set (4.1\% and $1.6 \%)$, some degree of error in the model's prediction is expected.

\section{Discussion and Limitations}

The results from the multinomial logistic regression presented above suggest a significant correlation between commuter benefits and transportation mode choice. Specifically, the provision of free car parking and no other benefits is strongly associated with a reduced likelihood to ride public transportation, walk, or cycle to work. Public transportation benefits alone are associated with an increased likelihood of riding public transportation, as well as walking. The correlation between public transportation benefits and walking to work is unexpected, but it could be that the significance of the public transportation benefit for the choice between walking and driving is capturing some aspect of urbanity not otherwise measured by the control variables for urbanity in our model. It may also be related to the high share of federal workers with public transportation benefits in the Washington, DC, region. Federal workers who walk to work may still have a public transportation benefit available to them as a "backup," even though they only rarely ride public transportation.

Bike/walk benefits were significant for the choice between cycling and driving, as expected. Although some commuters who walk to work may also benefit from showers/lockers, this analysis did not find a significant effect for these facilities for the choice between walking and driving in the full model. It is likely that most regular pedestrians would not need a shower after walking to work.

Providing a public transportation benefit along with bike/walk benefits was associated with an increased likelihood to ride public transportation, walk, and cycle. Compared to all other benefit combinations, including bike/walk benefits alone, the odds ratios for walking and cycling were highest (odds ratios of 2.549 for walking and 6.257 for cycling) for this benefit combination. However, the odds ratio 
for public transportation (odds ratio of 9.627) was lower with combined public transportation and bike/walk benefits than for commuters with public transportation benefits only (odds ratio of 11.337). This suggests that joint provision of public transportation and walk/bike benefits may encourage commuters to choose walking or cycling over driving while using public transportation as a "backup" alternative in case of inclement weather or unexpected emergencies. Moreover, the joint provision of public transportation and bike/walk benefits may attract at least some commuters away from public transportation to walking and cycling. These substitutions are more likely if commute distances are short enough for walking and cycling and if land-uses support walking, cycling, and public transportation. While our full model controls for commute trip distance, population density, household location in the urban core, transit access, and bikeway supply, we still find the combined provision of public transportation benefits and bike/walk benefits to be associated with the highest odds ratios for walking and cycling.

Combining free car parking with public transportation benefits and bike/walk benefits was associated with either the same or reduced odds for choosing one of the alternatives to driving. In other words, no benefit combination that included free car parking was associated with increased odds for riding public transportation, walking, or cycling to work. Providing free car parking alongside public transportation benefits was not associated with significantly differing odds compared to providing no benefits at all. Providing free car parking along with bike/walk benefits was associated with a lower likelihood of riding public transportation or walking to work. The joint provision of free car parking, public transportation benefits, and bike/walk benefits was associated with reduced odds of riding public transportation, but not differing odds for walking or cycling to work. This suggests that benefit combinations that include free car parking either overwhelm or render insignificant the positive effects of benefits for public transportation, walking, and cycling. Additional information about the 'quality' and 'quantity' of the benefits would strengthen such a finding. The MWCOG dataset only included dummy variables indicating the presence of a benefit, but did not include information about the quality or quantity of the benefit.

Regarding the additional control variables, findings are generally consistent with relationships reported in most other studies. Gender and ethnicity/race are associated with differing odds for walking and cycling, but ethnicity/race has a stronger correlation with walking while gender has a stronger correlation with cycling. Our results support other findings that men tend to be disproportionately represented 
in U.S. cycling, and non-white populations tend to be disproportionately underrepresented in U.S. cycling.

Income's negative association with public transportation is theoretically expected, and its positive association with cycling is consistent with other recent studies (Buehler 2012). The presence of one or more children in a household was associated with a reduced likelihood of riding public transportation and walking to work. This is theoretically expected, because households with children may have more rigid time budgets related to daycare and school schedules that lead to more triplinking, among other factors.

Car access is negatively associated with riding public transportation, walking, and cycling. Transit access is positively associated with riding public transportation and bicycle access is positively associated with cycling. Car access makes driving a viable alternative to public transportation, walking, and cycling. Moreover, individuals who wish to drive to work may be more likely to own an automobile. Walking and cycling are related to shorter commute distances, as expected. Population density and living in the urban core are also positively correlated with public transportation, walking, and cycling. This finding likely captures differences in infrastructure as well as other policy and cultural factors associated with higher rates of public transportation use, walking, and cycling. Self-selection could also play a role in these findings, as individuals with unobserved preferences for riding public transportation, walking, and cycling may choose to live in the regional core in higher rates than the inner suburbs. Bikeway supply is positively associated with walking and cycling, and because shared-use paths are included it is reasonable to assume that these facilities could be used by both pedestrians and cyclists. Finally, cycling is affected by season of the year, with higher rates in the warmer months of the year. This is consistent with other studies that find cycling to be significantly correlated with weather features such as temperature and precipitation.

Future studies about the interaction of commuter benefits could overcome some of the shortcomings of this study. First, the travel survey only collected binary benefit data, so the quality and quantity of the benefits provided could not be assessed. Future analyses should attempt to refine this analysis by assessing the impact of changes in the magnitude of benefits on mode choice. For example, such studies could measure the amount of free car parking, the dollar value of public transportation benefits, the number and quality of showers and changing facilities, and the amount and type of bicycle parking. Studies already control for some of these variables individually, but very few are able to simultaneously control for 
benefits for driving, riding public transportation, walking, and cycling. In addition, future analyses could identify distinct benefits for cycling and walking and treat them separately to further refine our understanding of the effect of these benefits.

Second, there are limitations related to several of the variables included in the model. The survey instrument only captured the usual main commute mode. As a result, the analysis could not evaluate the relationship between commute benefits and chained- or mixed-mode commuting. A future analysis of commute benefits and mode choice could examine whether the effect of combined benefit packages on mode choice is distinct for those commuters who combine multiple modes compared to those commuters relying on a single mode. In addition, the measures of transit access and bikeway supply did not incorporate quality measures that could relate to the impact of these measures on commute mode choice. Future studies could attempt to capture quality measures such as transit headways and traffic speeds or volumes along bikeways. Finally, commute travel time could be incorporated to assess the impact of travel time on mode choices, especially if travel time estimates for all commute modes are available.

Third, endogeneity and selection bias are limitations of our analysis, due to the cross-sectional and observational nature of the data. The potential for endogeneity and selection bias suggest caution should be taken in interpreting the results of our study. This study can report a correlation between mode choice and commuter benefits, but is not designed to assess a causal relationship. Structural Equations Models and other statistical techniques, combined with better data, could help shed light on the direction of causation.

Fourth, studies of this kind are vulnerable to omitted variable bias, and the analysis could potentially be improved by the addition of new explanatory measures or the improvement of measures already included in the model. For example, more controls for workplace neighborhood characteristics, such as density and transit access, may capture effects not included in this analysis.

Last, this study is based on the Washington, DC region, which is home to the U.S. federal government and is thus not necessarily representative of the rest of the U.S. Studies from other U.S. cities and regions could help solidify the results of this study.

Whatever the limitations of this study, it overcomes many shortcomings of previous studies in this field by including benefits for walking and cycling alongside benefits for driving and riding public transportation, as well as combinations of 
these benefits. Moreover, it utilizes revealed-preference individual-level data and control measures for several neighborhood-, household-, and individual-level characteristics.

\section{Conclusion}

Overall, our results support earlier findings in the literature that suggest commuter benefits for walking, cycling, and public transportation may be effective at supporting TDM objectives. Free car parking tends to be associated with more driving to work, public transportation benefits tend to be associated with riding public transportation, and trip-end facilities at work such as showers/lockers and bike parking tend to support walking or cycling. Our results also add to the literature by presenting an evaluation of the joint supply of benefits. While benefits for alternatives to driving are associated with individuals choosing to walk, cycle, and ride public transportation, free car parking is associated with driving, and the joint provision of free car parking along with these other benefits may blunt the efficacy of efforts to get commuters to walk, cycle, and ride public transportation to work.

\section{Acknowledgment}

This paper is partially based on data from a two-year research project funded by the U.S. Department of Transportation, "Determinants of Bicycling in the Washington, DC Area." It is part of the Research Initiatives Program of the Mid-Atlantic University Transportation Center (MAUTC).

\section{References}

Bachand-Marleau, Julie, Jacob Larsen, and Ahmed M El-Geneidy. 2011. Muchanticipated marriage of cycling and transit. Transportation Research Record 2247 (1): 109-117.

Block-Schachter, David. 2009. The myth of the single mode man: How the mobility pass better meets actual travel demand. Master's Thesis, Massachusetts Institute of Technology, Cambridge, MA.

Blumenberg, Evelyn. 2002. On the way to work: Welfare participants and barriers to employment. Economic Development Quarterly 16(4):314-325.

Boyd, Brent, Melissa Chow, Robert Johnson, and Alexander Smith. 2003. Analysis of effects of fare-free transit program on student commuting mode shares: 
BruinGo at University of California at Los Angeles. Transportation Research Record 1835(1): 101-110.

Brown, Jeffrey, Daniel Baldwin Hess, and Donald Shoup. 2003. Fare-free public transit at universities: An evaluation. Journal of Planning Education and Research no. 23 (1):69-82.

Buehler, Ralph. 2011. Trends and determinants of cycling in the Washington, DC Region. Report prepared for the U.S. Department of Transportation, Research and Innovative Technology Administration, Washington, DC, and the MidAtlantic University Transportation Research Consortium (MAUTC), University Park, PA.

Buehler, Ralph. 2012. Determinants of bicycle commuting in the Washington, DC region: The role of bicycle parking, cyclist showers, and free car parking at work. Transportation Research Part D: Transport and Environment 17(7): 525-531.

Cameron, C. A. , and P. K. Trivedi. 2010. Microeconometrics Using Stata: Revised Edition: Stata Press.

Cervero, Robert. 1990. Transit pricing research. Transportation 17(2): 117-139.

Cervero, Robert. 1991. Congestion, growth and public choices. University of California Transportation Center.

Cervero, Robert, and Michael Duncan. 2003. Walking, bicycling, and urban landscapes: Evidence from the San Francisco Bay Area. American Journal of Public Health 93(9): 1478-1483.

Dill, Jennifer, and Erin Wardell. 2007. Factors affecting worksite mode choice: Findings from Portland, Oregon. Transportation Research Record 1994(1): 51-57.

EPA. 2007. Commuter tax benefits: Implementing commuter benefits as one of the nation's best workplaces for commuters. Office of Air and Radiation.

Ewing, Reid, and Robert Cervero. 2010. Travel and the built environment. Journal of the American Planning Association 76(3): 265-294.

Ewing, Reid, and Eric Dumbaugh. 2009. The Built environment and traffic safety: A review of empirical evidence. Journal of Planning Literature 23(4):347-367.

FHWA. Contemporary approaches to parking pricing: A primer 2012a. Available from www.ops.fhwa.dot.gov/publications/fhwahop12026/. 
FHWA. Integrating demand management into the transportation planning process: a desk reference 2012b. Available from http://www.ops.fhwa.dot.gov/ publications/fhwahop12035/fhwahop12035.pdf.

Giuliano, Genevieve. 1992. Transportation demand management: Promise or panacea? Journal of the American Planning Association 58(3): 327-335.

Goddard, Tara B., Susan L. Handy, Xinyu Cao, and Patricia L. Mokhtarian. 2006. Voyage of the S.S. Minivan: Women's travel behavior in traditional and suburban neighborhoods. Transportation Research Record 1956(1): 141-148.

Habibian, M., and M. Kermanshah. 2011. Exploring the role of transportation demand management policies' interactions. Scientia Iranica 18(5): 1037-1044.

Herzog, Erik, Stacey Bricka, Lucie Audette, and Jeffra Rockwell. 2006. Do employee commuter benefits reduce vehicle emissions and fuel consumption? Results of fall 2004 survey of Best Workplaces for Commuters. Transportation Research Record 1956(1): 34-41.

Hess, Daniel Baldwin. 2001. Effect of free parking on commuter mode choice: Evidence from travel diary data. Transportation Research Record 1753(1): 35-42.

IRS. 2013. Employer's Tax Guide to Fringe Benefits.

Marsden, Greg. 2006. The evidence base for parking policies: A review. Transport Policy 13(6): 447-457.

MWCOG. State of the Commute Survey Report 2007. Available from http://www. mwcog.org/store/item.asp?PUBLICATION_ID=335.

MWCOG.2010.2007/2008 TPB Household Travel Survey:Technical Documentation. Available by request.

Potter, Stephen, Marcus Enoch, Tom Rye, Colin Black, and Barry Ubbels. 2006. Tax Treatment of employer commuting support: An international review. Transport Reviews 26 (2): 221-237.

Pucher, John. 1988. Urban travel behavior as the outcome of public policy: The example of modal-split in Western Europe and North America. Journal of the American Planning Association 54(4): 509-520.

Pucher,John. 2004. Public transportation. In The Geography of Urban Transportation, Third Edition, edited by Susan Hanson and Genevieve Giuliano. The Guilford Press. 
Pucher, John, and Ralph Buehler. 2012. Integration of cycling with public transportation. In City Cycling, edited by John Pucher and Ralph Buehler. The MIT Press.

Pucher, John, Jennifer Dill, and Susan Handy. 2010. Infrastructure, programs, and policies to increase bicycling: An international review. Preventive Medicine 50: S106-S125.

Pucher, John, Jan Garrard, and Stephen Greaves. 2011. Cycling down under: A comparative analysis of bicycling trends and policies in Sydney and Melbourne. Journal of Transport Geography 19(2): 332-345.

Rivasplata, Charles, Adam Smith, and Hiroyuki Iseki. 2012. Transit coordination in the U.S.: A survey of current practice. Journal of Public Transportation 5(1): 53-73.

Saelens, Brian E., James F. Sallis, and Lawrence D. Frank. 2003. Environmental correlates of walking and cycling: Findings from the transportation, urban design, and planning literatures. Annals of Behavioral Medicine 25(2): 80-91.

Shoup, Donald. 2005. The High Cost of Free Parking. Planners Press.

Shoup, Donald C. 1997. Evaluating the effects of cashing out employer-paid parking: eight case studies. Transport Policy 4(4): 201-216.

Small, Kenneth A., and Erik T. Verhoef. 2007. The Economics of Urban Transportation: Routledge.

Stoll, Michael A. 2005. Job Sprawl and the Spatial Mismatch Between Blacks and Jobs: Brookings Institution Metropolitan Policy Program.

Taylor, Brian D., and Paul M. Ong. 1995. Spatial mismatch or automobile mismatch? An examination of race, residence and commuting in U.S. metropolitan areas. Urban Studies 32(9): 1453-1473.

TCRP. 2002. Public agency guidance on employer-based TDM programs and employer technical memorandum characteristics of effective TDM programs. Transportation Research Board.

TCRP. 2003. Parking management and supply. Transportation Research Board.

TCRP. 2005. Analyzing the effectiveness of commuter benefit programs. Transportation Research Board. 
TCRP. 2010. Employer and institutional TDM strategies. Transportation Research Board.

TTI. Urban Mobility Report 2011. Available from http://mobility.tamu.edu/ files/2011/09/national-table_7.pdf.

USCB. 2010. American Fact Finder. Washington, DC: U.S. Department of Commerce.

Wachs, Martin. 1990. Transportation demand management: Policy implications of recent behavioral research. The University of California Transportation Center 23.

Wardman, Mark, Miles Tight, and Matthew Page. 2007. Factors influencing the propensity to cycle to work. Transportation Research Part A: Policy and Practice 41(4): 339-350.

Washbrook, Kevin, Wolfgang Haider, and Mark Jaccard. 2006. Estimating Commuter mode choice: A discrete choice analysis of the impact of road pricing and parking charges. Transportation 33(6): 621-639.

Willson, Richard W. 1992. Estimating the travel and parking demand effects of employer-paid parking. Regional Science and Urban Economics 22(1): 133-145.

Willson, Richard W., and Donald C. Shoup. 1990. Parking subsidies and travel choices: Assessing the evidence. Transportation 17(2): 141-157.

Winters, Meghan, Michael Brauer, Eleanor M. Setton, and Kay Teschke. 2010. Built environment influences on healthy transportation choices: Bicycling versus driving. Journal of Urban Health 87(6): 969-993.

WMATA. Metro Facts 2011. Available from http://www.wmata.com/about_metro/ docs/metrofacts.pdf.

\section{About the Authors}

ANDREA HAMRE (ahamre@vt.edu) is a Ph.D. candidate in Urban Affairs \& Planning at Virginia Tech's Alexandria Center. She has a master's degree in Applied Economics from Virginia Tech and a bachelor's degree in Environmental Studies from Middlebury College. Her research interests include multimodalism, commuter benefits, and active travel. 
RAlPh BuehleR, Ph.D. (ralphbu@vt.edu) is an Associate Professor in Urban Affairs \& Planning and a Faculty Fellow with the Metropolitan Institute at Virginia Tech's Alexandria Center. Most of his research has an international comparative perspective, contrasting transport and land-use policies, transport systems, and travel behavior in Western Europe and North America. His research interests include the influence of transport policy, land use, socio-demographics on travel behavior; active travel and public health; and public transport demand, supply, and financial efficiency. 